\title{
Stilovi sučeljavanja sa stresom u odnosu na različite dijagnoze psihičkih poremećaja
}

1 Zlata Pjević

1 Slađana Štrkalj Ivezić

2 Anja Melada

1 Klinika za psihijatriju Vrapče

2 Klinika za psihijatriju, Klinička bolnica Dubrava

\section{Sažetak}

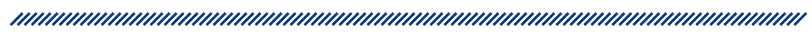

Uvod: Stres je jedan od najčešćih pokretača procesa koji dovode do psihičkih poremećaja. Cilj je istraživanja bio utvrditi postoje li razlike u stilu sučeljavanja sa stresom između sudionika s psihičkim poremećajima u odnosu na zdravu populaciju te razlike u stilovima sučeljavanja između sudionika s mentalnim poremećajima s obzirom na demografske karakteristike. Metode: Sudionici: $\mathrm{U}$ istraživanju je sudjelovalo 120 sudionika podijeljenih u četiri skupine od 30 sudionika. Sudionici s dijagnozom psihičke bolesti bili su podijeljeni u tri skupine: sudionici s depresivnim poremećajem, anksioznim poremećajem i psihotičnim poremećajem te prema spolu, stupnju obrazovanja, dobi, radnom i bračnom statusu, dužini liječenja i broju hospitalizacija. Četvrtu su skupinu činili zdravi sudionici. Instrumenti: Primijenjena je adaptirana verzija dispozicijskog oblika upitnika COPE (Coping Orientation to Problems Experienced). Rezultati: Između skupina oboljelih od psihičke bolesti i zdravih u stilovima sučeljavanja pokazala se statistički značajna razlika u: pozitivnoj interpretaciji, negiranju, ponašajnom dezangažmanu, alkoholu, fizičkoj izolaciji i potiskivanju emocija te razlike u odnosu na spol, dob, bračni status, zanimanje i zaposlenje. Rasprava: Razlike u sučeljavanju kod oboljelih od psihičkih poremećaja nisu određene njihovom psihopatologijom, što je u skladu s istraživanjima drugih istraživača. Sudionici u istraživanju prošli su ili je bilo u tijeku liječenje u dnevnoj bolnici gdje se primjenjuju psihosocijalne metode liječenja, što je moglo utjecati na njihove stilove sučeljavanja. Zaključak: Rezultati istraživanja potvrđuju da se zdrave osobe koriste funkcionalnijim stilovima sučeljavanja u odnosu na oboljele od psihičkih poremećaja. Nismo pronašli specifične stilove sučeljavanja u odnosu na pojedine dijagnostičke skupine, što govori u prilog podatcima da sučeljavanje ovisi o brojnim faktorima.

Ključne riječi: stres, sučeljavanje sa stresom, stil sučeljavanja, psihobiosocijalni model, psihosocijalne intervencije

Datum primitka: 09.06.2015.

Datum prihvaćanja: 08.09.2015.

\section{Adresa za dopisivanje:}

Zlata Pjević, dipl. med. techn.

Zavod za socijalnu psihijatriju, Klinika za psihijatriju Vrapče Bolnička 32, 10000 Zagreb

E-pošta: zlata.pjevic@bolnica-vrapce.hr 


\section{Uvod}

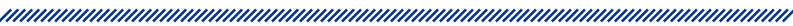

Psihički poremećaji najčešće nastaju interakcijom između bioloških, psiholoških i socijalnih faktora, a stres je jedan od najčešćih pokretača procesa koji dovode do simptoma psihičkog poremećaja te je i primarni uzročnik određenih psihičkih poremećaja.

Stilovi sučeljavanja sa stresom mogu se grupirati prema dva temeljna kriterija: vrsta reakcije (kognitivne/bihevioralne, aktivne/pasivne) i funkcija odnosno svrha pojedinog stila sučeljavanja (približavanje/izbjegavanje, sučeljavanje usmjereno na problem/emocije odnosno na uzrok/simptome) ${ }^{1}$. Lazarusova je podjela na stilove sučeljavanja usmjerene na problem i emocije najčešći način podjele ovih stilova u odnosu na njihovu funkciju. Istraživanja pokazuju da se u stresnim situacijama najčešće primjenjuju obje skupine stilova sučeljavanja ${ }^{2}$. Endler i Parker $(1990)^{3}$ identificirali su i treći stil sučeljavanja koji se naziva sučeljavanje izbjegavanjem, a odnosi se na kognitivne, emocionalne ili ponašajne pokušaje udaljavanja od izvora stresa ili od psihičkih i tjelesnih reakcija na stresor.

Odgovor na stres može biti pod utjecajem mnogih varijabli, procjena stresora spregnuta je sa sposobnostima pojedinca da se suoči s izazovom, što predstavlja djelomično značajan faktor u određivanju bihevioralnog i biološkog ishoda ${ }^{2,4,5}$. Određeni stilovi sučeljavanja prevladavaju u određenim patološkim stanjima. U depresivnim poremećajima prevladava emocijski fokusirano sučeljavanje, djelomično emocionalno sadržavanje ${ }^{6,7,8}$ te ruminacija ${ }^{9}$ uz smanjeno korištenje kognitivnim restrukturiranjem ${ }^{7}$ i traženjem podrške okoline ${ }^{10,11}$. Prema nekim studijama, uspoređujući stilove sučeljavanja osoba s depresivnim poremećajem i zdravih osoba pokazalo se da se osobe s depresivnim poremećajem češće koriste emocionalnim ventiliranjem, maštanjem, izbjegavanjem i traženjem emocionalne podrške, a manje su se koristile sučeljavanjem prema rješavanju problema $^{12,13}$. Pacijenti s anksioznim poremećajem u komorbiditetu s kardiovaskularnim bolestima također se koriste maladaptivnim stilovima sučeljavanja kao što su izolacija, inhibicija i somatizacija ${ }^{14}$. Istraživanja na području depresije i anksioznih poremećaja upućuju na češću primjenu izbjegavanja, kao i stilova sučeljavanja orijentiranih prema emocijama u odnosu na sučeljavanje orijentirano na rješavanje problema. Pacijenti sa shizofrenijom koriste se slabije prilagođenim meha- nizmima ${ }^{15} \mathrm{~s}$ obzirom na smanjeni kortizonski odgovor na psihosocijalni stres ${ }^{16}$, a prema naturalističkoj studiji praćenja oboljelih od shizofrenije, kvaliteta života više je povezana sa sučeljavanjem sa stresom nego sa samom psihopatologijom ${ }^{17}$. U istraživanju Vrdoljaka o socijalnom funkcioniranju osoba s dijagnozom shizofrenije u odnosu na načine sučeljavanja sa stresom vidljivo je da se osobe koje imaju manja oštećenja socijalnog funkcioniranja koriste povoljnijim načinima sučeljavanja u stresnoj situaciji ${ }^{18}$.

U razumijevanju svih psihičkih poremećaja kontekst psihobiosocijalnog modela koji uključuje teoriju osjetljivosti na stres ${ }^{19,20,21}$ objašnjava biološke predispozicije za psihičke poremećaje, stresore iz okoline i vulnerabilnost osobe. Psihosocijalne intervencije pomažu da se negativni efekti stresa ublaže i na taj način predstavljaju protektivne faktore jer povećavaju sučeljavanje i kompetenciju koji štite osobu od negativnih utjecaja stresnih događaja. Na bilo kojoj razini patologije uspješno sučeljavanje može značajno smanjiti socijalno i radno oštećenje te oštećenje brige o sebi22.

Cilj je istraživanja bio utvrditi postoje li statistički značajne razlike u stilu sučeljavanja sa stresom između sudionika s mentalnim poremećajima u odnosu na zdravu populaciju te između sudionika s mentalnim poremećajima u odnosu na stilove sučeljavanja sa stresom s obzirom na sljedeće parametre: spol, starost, bračni status, stručnu spremu (zanimanje), zaposlenost, dijagnozu, dužinu liječenja i broj hospitalizacija. Prepoznavanje razlika u sučeljavanjima omogućuje nam i bolje planiranje i tijek liječenja.

\section{Metode}

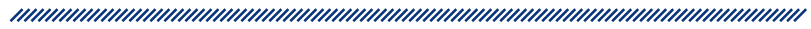

\section{Sudionici}

Ispitivanje je provedeno individualno $\mathrm{u}$ periodu od veljače do lipnja 2012. godine u Klinici za psihijatriju Vrapče. Za potrebe ispitivanja zatraženo je odobrenje Etičkog povjerenstva Klinike za psihijatriju Vrapče, koje je i dobiveno uz obrazloženje da se uz svaki upitnik priloži Informirani pristanak za svakog sudionika te Suglasnost za sudjelovanje. Sudionici su bili pacijenti koji su dolazili na ambulantno liječenje Zavoda za so- 
cijalnu psihijatriju u sklopu programa Dnevne bolnice, Odjela za rehabilitaciju u zajednici te Odjela za neuroze i granična stanja, a kontrolnu su skupinu činile osobe koje nemaju dijagnosticiran psihički poremećaj (zdrava populacija), odnosno medicinske sestre na trećoj godini izvanrednoga stručnog studija sestrinstva pri Zdravstvenom veleučilištu u Zagrebu koje su pohađale kolegij Zdravstvena njega psihijatrijskog bolesnika u Klinici za psihijatriju Vrapče. Ispitivač se prvo predstavio i ukratko objasnio da će ovo istraživanje poslužiti za izradu rada te da se njime ispituje kako se ljudi najčešće nose sa stresom prilikom rješavanja svakodnevnih problema. Sudionici su zamoljeni da na pitanja odgovore iskreno, uz napomenu da je ispitivanje anonimno i da će se rezultati upotrebljavati isključivo u svrhu istraživanja, odnosno za statističku obradu. Sudionicima je naglašeno da njihove upitnike neće vidjeti nitko drugi osim ispitivača. Sudionici su zamoljeni za suradnju, ali im je također naglašeno da mogu odbiti sudjelovanje i odustati kada god to žele. Na odjelu za liječenje neuroza i graničnih stanja deset ispitanika (uglavnom $\mathrm{s}$ dijagnozom PTSP-a) odbilo je ispunjavanje upitnika, a na Odjelu za rehabilitaciju u zajednici četiri su upitnika bila neadekvatno popunjena, i to kod ispitanika s dijagnozom shizofrenije. Svaki je upitnik imao svoju detaljnu uputu te su se ispitanici mogli obratiti ispitivaču u slučaju da je bilo potrebe za dodatnim objašnjenjem. Primjena upitnika trajala je oko 30 minuta. Ispitivanje komparabilne skupine osoba koje nemaju dijagnosticirani psihički poremećaj (zdrava populacija) provedeno je u malim grupama za vrijeme obavljanja vježbi u Klinici za psihijatriju Vrapče u sklopu kolegija Zdravstvena njega psihijatrijskog bolesnika.

$\mathrm{U}$ ispitivanju je sudjelovalo ukupno 120 sudionika podijeljenih u četiri skupine, od kojih su tri skupine sudionici s dijagnozom psihičke bolesti, a jednu skupinu od 30 sudionika činila je zdrava populacija (nemaju dijagnozu psihičke bolesti). Sudionici s dijagnozom psihičke bolesti bili su podijeljeni u tri skupine od 30 sudionika ( $\mathrm{N}=30$ ): osobe liječene od depresije, anksioznih poremećaja i psihotičnih poremećaja. Sudionici u tim skupinama dijagnostički su klasificirani prema Međunarodnoj klasifikaciji bolesti (MKB-10). U skupini ispitanika s depresivnim poremećajem bile su zastupljene dijagnoze: F32.1 (umjerena depresivna epizoda), F32.2 (teška depresivna epizoda bez psihotičnih simptoma), F33.1 (ponavljajući depresivni poremećaj, sadašnja epizoda umjerena) i F33.2 (ponavljajući depresivni poremećaj, sadašnja epizoda teška). U skupini sudionika s anksioznim poremećajem bile su zastupljene dija- gnoze: F40 (fobični anksiozni poremećaji), F41 (drugi anksiozni poremećaji), F43.0 (akutna reakcija na stres), F43.1 (posttraumatski stresni poremećaj) i F43.2 (poremećaj prilagodbe). U skupini s psihotičnim poremećajem su sudionici imali dijagnoze: F20.0 (paranoidna shizofrenija) i F25 (shizoafektivni poremećaj), dok su sva sudionika bila s dijagnozom F22 (perzistirajući sumanuti poremećaj) te dvije osobe s F23 (akutni prolazni psihotični poremećaj). Sudionike smo podijelili i prema spolu, stupnju obrazovanja, dobi, radnom i bračnom statusu (tablica 1) te dužini liječenja u mjesecima (tablica 2) i broju hospitalizacija (tablica 3). U skupini sudionika s anksioznim poremećajem bilo je dva puta više muškaraca, a u skupini zdrave populacije natpolovičnu su većinu činile žene. Što se tiče obrazovanja, najveći je udio sudionika bio sa završenom srednjom školom. U skupinama osoba s psihičkim poremećajem najmlađa je dob sudionika bila iz skupine osoba s psihotičnim poremećajem (prosjek 42 godine), dok je donja granica kod osoba s depresijom 41 do 63 godine (prosjek 51 godina). Najmlađi je sudionik bio iz skupine anksioznih bolesnika. Najveći prosjek liječenja imali su sudionici iz skupine osoba s psihotičnim poremećajem (13 godina) što je povezano i s vrlo ranim početkom bolesti. U broju hospitalizacija bilo je evidentirano samo bolničko liječenje, dok se liječenje u Dnevnoj bolnici tretiralo kao ambulantno liječenje. Većina sudionika s psihotičnim poremećajem bila je hospitalizirana u slučaju pogoršanja bolesti, dok se većina depresivnih sudionika liječila kroz programe Dnevne bolnice. U skupinama bolesne populacije najveći je broj zaposlenih bio s depresivnim poremećajem (63,3\%), dok je najveći broj nezaposlenih bio iz skupine osoba s psihozom (36,7 \%). Najviše umirovljenika bilo je u skupini anksioznog poremećaja (53\%). Najveći je broj sudionika koji živi u bračnoj zajednici bio u skupini sudionika koji imaju depresivni poremećaj (90\%), dok je u skupini sudionika s psihozom većina neoženjena $(66,7 \%)$.

\section{Instrumenti}

$U$ ispitivanju stilova sučeljavanja sa stresnim situacijama primijenjena je adaptirana verzija upitnika COPE (Coping Orientation to Problems Experienced). Autori su ovog upitnika Carver, Weintraub i Scheirer (1989) ${ }^{23}$. Adaptaciju upitnika za naše kulturalne uvjete napravili su autori Hudek-Knežević i Kardum (1993) ${ }^{24}$. Ovako adaptirani upitnik COPE sastoji se od 71 čestice koje čine 17 empirijski deriviranih skala, od kojih je 15 preuzeto iz izvornog (COPE) upitnika, dok specifični odgovori sudionika našeg područja sačinjavaju dvije dodatne 
Tablica 1. Podjela sudionika prema spolu, dobi, prosječnoj dobi, stupnju obrazovanja, radnom i bračnom statusu

\begin{tabular}{|c|c|c|c|c|c|c|c|}
\hline 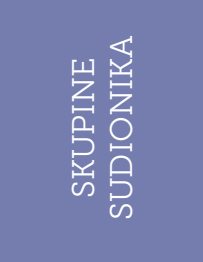 & 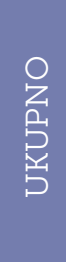 & $\begin{array}{l}\stackrel{1}{\circ} \\
\stackrel{n_{1}}{1}\end{array}$ & $\stackrel{m}{\circ}$ & 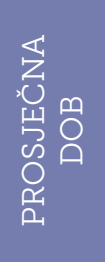 & 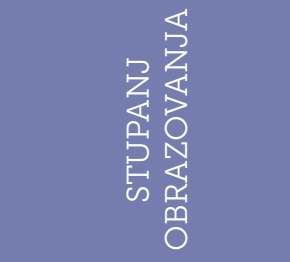 & 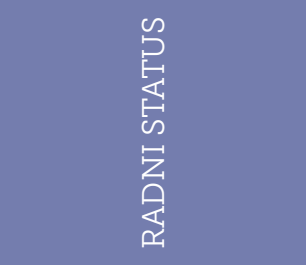 & 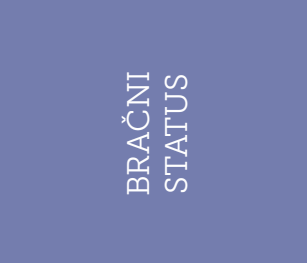 \\
\hline $\begin{array}{l}\text { OSOBE S } \\
\text { DEPRESIVNIM } \\
\text { POREMEĆAJEM }\end{array}$ & 30 & $\begin{array}{l}M-13(43,3 \%) \\
\grave{Z}-17(56,7 \%)\end{array}$ & $41-63$ & 51 god. & $\begin{aligned} \text { - OSNOVNA ŠKOLA: } 4 \\
\text { (13,3 \%) } \\
\text { - SREDNJA STRUČNA } \\
\text { SPREMA: } 23(76,7 \%) \\
\text { - VIŠA STRUČNA } \\
\text { SPREMA: } 1(3,3 \%) \\
\text { - VISOKA STRUČNA } \\
\text { SPREMA: } 2(6,7 \%)\end{aligned}$ & $\begin{aligned} & \text { ZAPOSLEN/A: } 19 \\
& (63,3 \%) \\
\text { - } & \text { NEZAPOSLEN/A: } \\
& 7(23,3 \%) \\
\text { - } & \text { U MIROVINI: } 4(13,3 \%) \\
\text { - } & \text { DRUGO: } 0(0,00 \%)\end{aligned}$ & 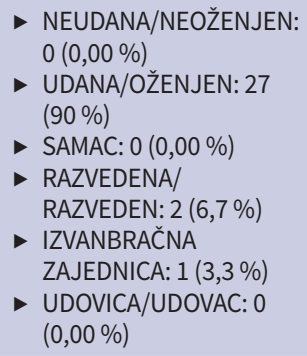 \\
\hline $\begin{array}{l}\text { OSOBE S } \\
\text { ANKSIOZNIM } \\
\text { POREMEĆAJEM }\end{array}$ & 30 & $\begin{array}{l}M-20(66,7 \%) \\
\check{Z}-10(33,3 \%)\end{array}$ & $20-66$ & 51 god. & $\begin{aligned} \text { OSNOVNA ŠKOLA: } 3 \\
\text { (10\%) } \\
\text { SREDNJA STRUČNA } \\
\text { SPREMA: } 21 \text { (70\%) } \\
\text { - VIŠA STRUČNA } \\
\text { SPREMA: } 3(10 \%) \\
\text { VISOKA STRUČNA } \\
\text { SPREMA: } 3(10 \%)\end{aligned}$ & $\begin{array}{l}\text { ZAPOSLEN/A: } 9(30 \%) \\
\text { NEZAPOSLEN/A: } 3 \\
\text { (10\%) } \\
\text { U MIROVINI: } 16(53 \%) \\
\text { - DRUGO: } 2(6,7 \%)\end{array}$ & $\begin{aligned} \text { - } & \text { NEUDANA/NEOŽENJEN: } \\
& 5(16,7 \%) \\
\text { - } & \text { UDANA/OŽENJEN: } 20 \\
& (66,7 \%) \\
\text { - } & \text { SAMAC: } 2(6,7 \%) \\
\text { - } & \text { RAZVEDENA/ } \\
& \text { RAZVEDEN: } 3(10 \%) \\
\text { - } & \text { IZVANBRAČNA } \\
& \text { ZAJEDNICA: } 0(0,00 \%) \\
\text { - } & \text { UDOVICA/UDOVAC: } 0 \\
& (0,00 \%)\end{aligned}$ \\
\hline $\begin{array}{l}\text { OSOBE S } \\
\text { PSIHOTIČNIM } \\
\text { POREMEĆAJEM }\end{array}$ & 30 & $\begin{array}{l}M-12(40 \%) \\
\grave{Z}-18(60 \%)\end{array}$ & $28-64$ & 42 god. & $\begin{aligned} \text { - OSNOVNA ŠKOLA: } 1 \\
\text { (3,3\%) } \\
\text { - SREDNJA STRUČNA } \\
\text { SPREMA: } 21(70 \%) \\
\text { - VIŠA STRUČNA } \\
\text { SPREMA: } 3(10 \%) \\
\text { - VISOKA STRUČNA } \\
\text { SPREMA: } 5(16,7 \%)\end{aligned}$ & $\begin{aligned} & \text { - } \text { ZAPOSLEN/A: } 4 \\
&(13,3 \%) \\
& \text { - } \text { NEZAPOSLEN/A: } 11 \\
&(36,7 \%) \\
& \text { - U MIROVINI: } 13 \\
& \\
& \text { (43,3\%) } \\
& \text { - DRUGO: } 2(6,7 \%)\end{aligned}$ & $\begin{aligned} & \text { NEUDANA/NEOŽENJEN: } \\
& 20(66,7 \%) \\
& \text { - } \text { UDANA/OŽENJEN: } 6 \\
&(6,7 \%) \\
& \text { - } \text { SAMAC: } 0(0,00 \%) \\
& \text { RAZVEDENA/ } \text { RAZV } \\
& \text { RAZVEDEN: } 2(6,7 \%) \\
& \text { - } \text { IZVANBRAČNA } \\
& \text { ZAJEDNICA: } 0(0,00 \%) \\
& \text { UDOVICA/UDOVAC: } 2 \\
& \\
&(6,7 \%)\end{aligned}$ \\
\hline $\begin{array}{l}\text { ZDRAVA } \\
\text { POPULACIJA }\end{array}$ & 30 & $\begin{array}{l}M-7(23,3 \%) \\
\check{Z}-23(76,7 \%)\end{array}$ & $27-57$ & 37 god. & $\begin{aligned} \text { - OSNOVNA ŠKOLA: } 0 \\
\text { (0,00 \%) } \\
\text { - SREDNJA STRUČNA } \\
\text { SPREMA: } 16(53,3 \%) \\
\text { - VIŠA STRUČNA } \\
\text { SPREMA: } 10(33,3 \%) \\
\text { - VISOKA STRUČNA } \\
\text { SPREMA: } 4(13,3 \%)\end{aligned}$ & $\begin{aligned} \text { - ZAPOSLEN/A: } 29 \\
\text { (96,7\%) } \\
\text { - NEZAPOSLEN/A: } \\
\text { O (0,00\%) } \\
\text { - U MIROVINI: } 0(0,00 \%) \\
\text { - DRUGO: } 1(3,3 \%)\end{aligned}$ & $\begin{aligned} & \text { - } \text { NEUDANA/NEOŽENJEN: } \\
& 10(33,3 \%) \\
& \text { - } \text { UDANA/OŽENJEN: } 18 \\
&(60,0 \%) \\
& \text { - } \text { SAMAC: } 0(0,00 \%) \\
& \text { - } \text { RAZVEDENA/ } \\
& \text { RAZVEDEN: } 2(6,7 \%) \\
& \text { - } \text { IZVANBRAČNA } \\
& \text { ZAJEDNICA: } 0(0,00 \%) \\
& \text { UDOVICA/UDOVAC: } 0 \\
& \\
& \text { (0,00\%) }\end{aligned}$ \\
\hline UKUPNO & 120 & $\begin{array}{l}M-52(43,3 \%) \\
\text { Ž- - } 8(56,7 \%)\end{array}$ & $20-66$ & 45 god. & $\begin{aligned} \text { OSNOVNA ŠKOLA: } 8 \\
\text { (6,7 \%) } \\
\text { SREDNJA STRUČNA } \\
\text { SPREMA: } 81 \text { ( } 67,5 \%) \\
\text { VIŠA STRUČNA } \\
\text { SPREMA: } 17(14,2 \%) \\
\text { VISOKA STRUČNA } \\
\text { SPREMA: } 14 \text { (11,7\%) }\end{aligned}$ & $\begin{aligned} & \text { ZAPOSLEN/A: } 61 \\
& (50,8 \%) \\
\text { - } & \text { NEZAPOSLEN/A: } \\
& 21(17,5 \%) \\
& \text { U MIROVINI: } 33 \\
& (27,5 \%) \\
\text { - } & \text { DRUGO: } 5(4,2 \%)\end{aligned}$ & $\begin{aligned} \text { - } & \text { NEUDANA/NEOŽENJEN: } \\
& 35(29,2 \%) \\
\text { - } & \text { UDANA/OŽENJEN: } 71 \\
& (59,2 \%) \\
\text { - } & \text { SAMAC: } 2(1,7 \%) \\
\text { - } & \text { RAZVEDENA/ } \\
& \text { RAZVEDEN: } 9(7,5 \%) \\
\text { - } & \text { IZVANBRAČNA } \\
& \text { ZAJEDNICA: } 1(0,8 \%) \\
\text { - } & \text { UDOVICA/UDOVAC: } 2 \\
& (1,7 \%)\end{aligned}$ \\
\hline
\end{tabular}


skale - skalu osamljivanja i skalu potiskivanja emocija. Upotrebljavao se dispozicijski oblik upitnika COPE. Odgovori su bodovani na skali Likertova tipa od pet stupnjeva (0 - 4), a glasili su „nikada se tako ne ponašam“, „katkad se tako ponašam“, „obično se tako ponašam“, "često se tako ponašam“ i „uvijek se tako ponašam“. Konačni rezultat svakog sudionika oblikuje se kao kompozit zbrajanja čestica koje tvore pojedinu skalu.

Upitnik COPE sastoji se od 17 skala koje čine sljedeće stilove sučeljavanja: 1. Pozitivna interpretacija i rast ličnosti odnosi se na viđenje dane situacije u povoljnom svjetlu ili korištenje dobrim stranama situacije. 2. Aktivno sučeljavanje odnosi se na poduzimanje akcije ili napora da bi se uklonio ili izbjegao stresor. 3. Planiranje se odnosi na razmišljanje o konfrontaciji sa stresom i suočavanje s naporima. 4. Prihvaćanje se odnosi na prihvaćanje činjenice da se stresni događaj dogodio $\mathrm{i}$ da je stvaran. 5. Obuzdavanje sučeljavanja odnosi se na pasivno sučeljavanje obuzdavanjem pokušaja sučeljavanja dok god to bude potrebno. 6. Potiskivanje kompeticijskih aktivnosti predstavlja usmjeravanje pažnje s drugih aktivnosti, kako bi se potpunije koncentriralo na sučeljavanje sa stresom. 7 . Negiranje se odnosi na pokušaje da se odbije realnost stresnog događaja. 8. Ponašajno izbjegavanje predstavlja odustajanje ili povlačenje napora u smjeru postizanja cilja s kojim interferira stresor. 9. Mentalno izbjegavanje odnosi se na psihološki dezangažman od cilja s kojim interferira stresor ma- štanjem, spavanjem i samodestruktivnim ponašanjem. 10. Traženje socijalne podrške zbog emocionalnih razloga odnosi se na primanje simpatije ili emocionalne podrške. 11. Traženje socijalne podrške zbog instrumentalnih razloga predstavlja traženje pomoći, informacija ili savjeta o tome što da radimo. 12. Ventiliranje emocija predstavlja povećanu svjesnost o stresnom događaju uz tendenciju da se emocije ventiliraju i izraze. 13. Humor se odnosi na korištenje šalama i humorom u vezi sa stresnim situacijama. 14. Alkohol predstavlja konzumaciju alkoholnih pića. 15. Religija predstavlja oslanjanje na vjeru u boga i religijska osjećanja. 16. Fizička izolacija odnosi se na tendenciju povlačenja od drugih ljudi i potrebu da se bude sam. 17. Potiskivanje emocija predstavlja neizražavanje emocija. Ove su skale podvrgnute faktorskoj analizi drugog reda u istraživanju Knežević (1993) 24 na uzorku od 403 sudionika u sklopu prve adaptacije skale u našim kulturalnim uvjetima. Dobivena su tri faktora koje su autori nazvali: problemu usmjereno sučeljavanje, emocijama usmjereno sučeljavanje i sučeljavanje izbjegavanjem. Pouzdanost tipa Cronbach alpha za pojedine skale kreće se u rasponu od 0,52 do 0,9 , a test-retest pouzdanosti u rasponu od 0,34 do $0,72^{24}$.

Pouzdanost upitnika COPE, procijenjena Cronbachovim alpha koeficijentom, na našem ukupnom uzorku iznosi 0,8041 , dok se za pojedine ljestvice kreće u rasponu od $-0,2$ do 0,64 .

\begin{tabular}{|c|c|c|c|}
\hline & Tablica 2. Dužina liječenja u mjesecima & PROSJEK \\
\hline SKUPINE SUDIONIKA & MINIMUM & MAKSIMUM & 6 godina (72 mjeseca) \\
\hline $\begin{array}{c}\text { OSOBE S DEPRESIVNIM } \\
\text { POREMEĆAJEM }\end{array}$ & 2 mjeseca & 480 mjeseci & 6 godina (72 mjeseca) \\
$\begin{array}{c}\text { OSOBE S ANKSIOZNIM } \\
\text { POREMEĆAJEM }\end{array}$ & 2 mjeseca & 288 mjeseci & 13 godina (136 mjeseci) \\
\hline $\begin{array}{c}\text { OSOBE S PSIHOTIČNIM } \\
\text { POREMEĆAJEM }\end{array}$ & 0 mjeseci & 384 mjeseca & \\
\hline
\end{tabular}

\begin{tabular}{|c|c|c|c|}
\hline \multicolumn{4}{|c|}{ Tablica 3. Broj hospitalizacija } \\
\hline SKUPINE SUDIONIKA & MINIMUM & MAKSIMUM & PROSJEK \\
\hline $\begin{array}{c}\text { OSOBE S DEPRESIVNIM } \\
\text { POREMEĆAJEM }\end{array}$ & 0 & 5 & 1 hospitalizacija \\
\hline $\begin{array}{c}\text { OSOBE S ANKSIOZNIM } \\
\text { POREMEĆAJEM }\end{array}$ & 0 & 15 & 3 hospitalizacija \\
\hline $\begin{array}{c}\text { OSOBE S PSIHOTIČNIM } \\
\text { POREMEĆAJEM }\end{array}$ & 0 & 50 & 7 hospitalizacija \\
\hline
\end{tabular}


Navedeni stilovi sučeljavanja uključuju različito grupirano sučeljavanje. Sučeljavanje usmjereno na problem uključuje: pozitivnu interpretaciju i rast ličnosti, aktivno sučeljavanje, planiranje, prihvaćanje, obuzdavanje sučeljavanja i potiskivanje kompetencijskih aktivnosti. Sučeljavanje usmjereno na emocije uključuje: traženje socijalne podrške zbog emocionalnih razloga i zbog instrumentalnih razloga te ventiliranje emocija. Stilovi izbjegavanja uključuju: negiranje, ponašajno i mentalno izbjegavanje, humor, religiju, alkohol, fizičku izolaciju i potiskivanje emocija.

\section{Rezultati}

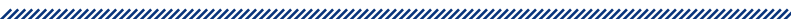

Primjenom upitnika COPE željelo se provjeriti postoji li razlika u stilovima sučeljavanja sa stresom između skupina kojima je dijagnosticirana psihička bolest te razlikuju li se navedene skupine u odnosu na komparabilnu skupinu koja predstavlja zdravu populaciju.
U tablicama 4, 5, 6 i 7 prikazani su rasponi, aritmetičke sredine i standardne devijacije za svaku pojedinu skupinu te sve stilove sučeljavanja i tri izdvojena faktora (stil sučeljavanja usmjeren na problem, stil sučeljavanja usmjeren na emocije te stil izbjegavanja). Kako bismo provjerili postoji li statistički značajna razlika između pojedinih stilova sučeljavanja u odnosu na različite skupine sudionika kojima je dijagnosticirana psihička bolest i skupinu koja predstavlja zdravu populaciju, provedena je analiza varijance. $\mathrm{U}$ tablici 8 prikazane su dobivene vrijednosti. Iz tablice 8 vidljivo je da je testiranje značajnosti razlika između skupina oboljelih od psihičke bolesti i zdravih u stilovima sučeljavanja pokazalo statistički značajne razlike u: pozitivnoj interpretaciji $(F=4,861 ; p=0,003)$, negiranju $(F=4,097 ; p=0,008)$, ponašajnom dezangažmanu $(F=11,391 ; p=0)$, alkoholu ( $F=8,567 ; p=0)$, fizičkoj izolaciji $(F=15,903 ; p=0)$ i potiskivanju emocija $(F=5,278 ; p=0,002)$. Kako bismo utvrdili smjer navedenih razlika, učinjena je dodatna analiza Scheffeovim post hoc testom. Scheffeov post hoc test pokazao je da se zdrava populacija statistički značajno češće koristila pozitivnom interpretacijom

\begin{tabular}{|c|c|c|c|c|c|}
\hline $\begin{array}{c}\text { Tablica 4. Prosječne vrijednosti, raspon i raspršenja rezultata } \\
\text { na skalama suočavanja za skupinu depresivnih }\end{array}$ \\
\hline Pozitivna interpretacija & M & SD & Min. & Maks. \\
\hline Aktivno suočavanje & 6,23 & 3,370 & 1 & 14 \\
\hline Planiranje & 7,57 & 3,360 & 2 & 15 \\
\hline Prihvaćanje & 10,03 & 3,970 & 3 & 18 \\
\hline Obuzdavanje suočavanja & 7,66 & 3,015 & 3 & 15 \\
\hline Potiskivanje kompeticijskih aktivnosti & 7,37 & 2,918 & 1 & 16 \\
\hline Negiranje & 5,10 & 2,369 & 1 & 12 \\
\hline Ponašajni dezangažman & 4,13 & 3,598 & 0 & 15 \\
\hline Mentalni dezangažman & 8,40 & 3,490 & 2 & 17 \\
\hline Socijalna podrška emocije & 10,63 & 5,027 & 2 & 22 \\
\hline Socijalna podrška instrumentalno & 6,03 & 3,489 & 2 & 15 \\
\hline Ventiliranje emocija & 7,57 & 3,963 & 2 & 19 \\
\hline Humor & 6,03 & 2,895 & 2 & 12 \\
\hline Alkohol & 2,80 & 3,428 & 0 & 12 \\
\hline Religija & 5,27 & 4,770 & 0 & 16 \\
\hline Fižčka izolacija & 6,90 & 5,202 & 0 & 16 \\
\hline Potiskivanje emocija & 10,07 & 3,581 & 4 & 16 \\
\hline Suočavanja usmjerena na problem & 7,57 & 3,441 & 2 & 15 \\
\hline Suočavanje usmjereno na emocije & 10,47 & 4,776 & 1 & 22 \\
\hline Strategije izbjegavanja & 4,97 & 1,921 & 1 & 8 \\
\hline
\end{tabular}


u odnosu na depresivne ( $M D=2,9 ; p=0,01)$. Također je vidljivo da se skupina oboljelih od psihoza u odnosu na depresivne sudionike statistički značajno češće $(M D=2,633 ; p=0,025)$ koristila pozitivnom interpretacijom kao stilom sučeljavanja. Negiranje se pokazalo kao statistički značajno češće primjenjivana strategija sučeljavanja kod sudionika iz skupine anksioznih $(M D=2,3$; $\mathrm{p}=0,041)$ i skupine psihoza (MD = 2,367; $\mathrm{p}=0,034) \mathrm{u}$ odnosu na zdravu populaciju. Sve tri skupine oboljelih od psihičkih poremećaja prema dobivenoj post hoc analizi statistički su se značajno češće koristile ponašajnim dezangažmanom kao stilom sučeljavanja u odnosu na zdravu populaciju (depresivni $M D=4,4 ; p=0$, anksiozni $M D=3,5 ; p=0$ i psihoze $M D=2,33 ; p=0$ ). Alkohol se pokazao kao statistički značajno češće primjenjivana strategija sučeljavanja kod oboljelih od depresije u odnosu na zdravu populaciju ( $M D=4,6 ; p=0)$ i psihoze $(M D=3,23 ; p=0,027)$. Skupina oboljelih od psihoza prema dobivenim rezultatima statistički se značajno češće $(M D=3,83 ; p=0,047)$ koristila religijom kao stilom sučeljavanja u odnosu na zdravu populaciju. Fizička izolacija pokazala se statistički značajno češćom strategijom sučeljavanja kod skupine anksioznih ( $M D=4,4 ; p=0)$ i psihoza (MD=3,867; $p=0,003)$ u odnosu na zdravu populaciju. Skupina oboljelih od depresivnog poremećaja statistički se značajno češće koristila fizičkom izolacijom kao stilom sučeljavanja u odnosu na pacijente s psihozama ( $M D=3,0 ; p=0,35$ ) i zdravu populaciju $(M D=6,867 ; p=0)$. Potiskivanje emocija kao strategija sučeljavanja pokazalo se statistički značajno češće primjenjivano kod depresivnih u odnosu na zdravu populaciju (MD = 3,2; $\mathrm{p}=0,005)$.

Preuzeta je i podjela na stilove sučeljavanja kakva je dobivena u istraživanju Hudek-Knežević i Kardum (1993) ${ }^{24}$. Razlikujemo stilove sučeljavanja usmjerene na problem (pozitivna interpretacija i rast ličnosti, aktivno sučeljavanje, planiranje, prihvaćanje, obuzdavanje sučeljavanja i potiskivanje kompeticijskih aktivnosti), stilove sučeljavanja usmjerene na emocije (traženje socijalne podrške zbog emocionalnih razloga i zbog instrumentalnih razloga te ventiliranje emocija) i stilove izbjegavanja (negiranje, ponašajno i mentalno izbjegavanje, humor, religija, alkohol, fizička izolacija i potiskivanje

\begin{tabular}{|c|c|c|c|c|}
$\begin{array}{c}\text { Tablica 5. Prosječne vrijednosti, raspon i raspršenja rezultata na skalama suočavanja } \\
\text { za skupinu anksioznih }\end{array}$ \\
\begin{tabular}{|c|c|c|c|c|}
\hline \\
\hline Pozitivna interpretacija
\end{tabular} & M & SD & Min. & Maks. \\
\hline Aktivno suočavanje & 7,77 & 2,897 & 3 & 15 \\
\hline Planiranje & 8,93 & 3,685 & 4 & 16 \\
\hline Prihvaćanje & 11,67 & 4,574 & 5 & 20 \\
\hline Obuzdavanje suočavanja & 8,73 & 3,183 & 4 & 15 \\
\hline Potiskivanje kompeticijskih aktivnosti & 7,43 & 3,048 & 3 & 16 \\
\hline Negiranje & 5,60 & 2,372 & 2 & 12 \\
\hline Ponašajni dezangažman & 4,37 & 2,988 & 0 & 13 \\
\hline Mentalni dezangažman & 7,50 & 3,511 & 1 & 14 \\
\hline Socijalna podrška emocije & 12,37 & 5,468 & 2 & 26 \\
\hline Socijalna podrška instrumentalno & 6,67 & 4,663 & 0 & 16 \\
\hline Ventiliranje emocija & 7,77 & 4,869 & 0 & 17 \\
\hline Humor & 6,87 & 3,137 & 2 & 12 \\
\hline Alkohol & 3,20 & 2,683 & 0 & 11 \\
\hline Religija & 4,63 & 5,308 & 0 & 16 \\
\hline Fizička izolacija & 6,27 & 5,626 & 0 & 16 \\
\hline Potiskivanje emocija & 7,60 & 4,477 & 0 & 16 \\
\hline Suočavanja usmjerena na problem & 6,70 & 3,861 & 0 & 14 \\
\hline Suočavanje usmjereno na emocije & 11,77 & 3,674 & 3 & 18 \\
\hline Strategije izbjegavanja & 5,20 & 2,295 & 1 & 10 \\
\hline
\end{tabular}


emocija). Iz tablice 8 vidljivo je da analiza varijance ne ukazuje na statistički značajne razlike u odnosu na pojedine stilove sučeljavanja, tj. da između stilova sučeljavanja na problem, stilova sučeljavanja na emocije te stilova izbjegavanja nema razlike između pojedinih skupina. Daljnjom analizom željelo se provjeriti postoje li razlike u odnosu na spol, dob, bračni status, zanimanje i zaposlenje kada govorimo o stilu sučeljavanja kod oboljelih od depresije, psihoza i anksioznih poremećaja.

U skupni oboljelih od anksioznih poremećaja pokazala se statistički značajna razlika između zaposlenih i nezaposlenih u korištenju religijom kao stilom sučeljavanja $(F=7,962 ; p=0,009)$. Pri tome su zaposleni skloniji religiji kao stilu sučeljavanja ( $M=7,21 ; \mathrm{SD}=6,051)$ u odnosu na nezaposlene ( $M=6,36 ; S D=3,472)$. $U$ skupini oboljelih od psihoza pokazalo se da postoji statistički značajna razlika između oženjenih i grupe neoženjenih i samaca u korištenju alkoholom kao stilom sučeljavanja $(F=7,815 ; p=0,009)$. Oženjeni su se pokazali skloniji alkoholu kao strategiji sučeljavanja $(M=4,5 ; S D=6,124) u$ odnosu na neoženjene i razvedene $(M=1,42 ; S D=2,22)$.
$\mathrm{U}$ istoj se skupini pokazalo da su neoženjeni i razvedeni statistički značajno skloniji religiji kao stilu sučeljavanja $(F=8,988 ; p=0,006)$. U skupini oboljelih od depresije uočila se statistički značajna razlika između muškaraca i žena kada govorimo o potiskivanju kao strategiji sučeljavanja ( $F=11,237, p=0,002)$. Žene u ovoj skupini statistički su se značajno češće koristile potiskivanjem emocija kao stilom sučeljavanja ( $M=7,88 ; S D=4,26) \mathrm{u}$ odnosu na muškarce ( $M=7,15 ; S D=2,03)$. $U$ istoj se skupini uočavala i statistički značajna razlika između sudionika sa završenom osnovnom školom i onih sa završenom srednjom školom kod mentalnog dezangažmana kao stila sučeljavanja $(F=10,66 ; p=0,003)$. Sudionici sa završenom srednjom školom statistički su se značajno češće koristili mentalnim dezangažmanom kao stilom sučeljavanja ( $M=10,78 ; S D=3,84)$. Potrebno je naglasiti da su sve navedene razlike vjerojatno jednim dijelom $i$ odraz neravnomjernog omjera u kojem je unutar svake kategorije zastupljen spol, zanimanje itd. Statističkom obradom pokušalo se provjeriti postoje li razlike u načinu sučeljavanja u odnosu na dužinu liječenja i broj hospitalizacija kod pojedine skupine oboljelih, no nisu

\begin{tabular}{|c|c|c|c|c|}
\hline & M & SD & Min. & Maks. \\
\hline Pozitivna interpretacija & 8,87 & 3,812 & 2 & 16 \\
\hline Aktivno suočavanje & 9,30 & 3,932 & 1 & 16 \\
\hline Planiranje & 12,00 & 4,871 & 1 & 20 \\
\hline Prihvaćanje & 9,20 & 3,448 & 3 & 16 \\
\hline Obuzdavanje suočavanja & 7,70 & 3,725 & 1 & 16 \\
\hline Potiskivanje kompeticijskih aktivnosti & 6,10 & 2,917 & 0 & 12 \\
\hline Negiranje & 4,43 & 3,350 & 0 & 15 \\
\hline Ponašajni dezangažman & 6,33 & 2,975 & 1 & 12 \\
\hline Mentalni dezangažman & 12,07 & 5,452 & 3 & 25 \\
\hline Socijalna podrška emocije & 8,67 & 4,922 & 0 & 16 \\
\hline Socijalna podrška instrumentalno & 8,97 & 5,068 & 0 & 20 \\
\hline Ventiliranje emocija & 5,63 & 3,429 & 0 & 12 \\
\hline Humor & 3,80 & 2,905 & 0 & 12 \\
\hline Alkohol & 2,03 & 3,459 & 0 & 16 \\
\hline Religija & 8,57 & 5,722 & 0 & 16 \\
\hline Fizička izolacija & 7,07 & 4,556 & 0 & 16 \\
\hline Potiskivanje emocija & 5,37 & 3,200 & 0 & 14 \\
\hline Suočavanja usmjerena na problem & 12,27 & 4,386 & 3 & 22 \\
\hline Suočavanje usmjereno na emocije & 4,73 & 2,303 & 0 & 8 \\
\hline Strategije izbjegavanja & 15,53 & 5,551 & 2 & 25 \\
\hline
\end{tabular}


uočene statistički značajne razlike. Iz početne je analize deskriptivne statistike za cijeli uzorak vidljivo da je u skupini osoba s psihotičnim poremećajem znatno veći broj hospitalizacija i duži sam tijek liječenja, no značajne razlike u stilovima sučeljavanja u odnosu na dužinu i tijek liječenja nisu zamijećene.

\section{Rasprava}

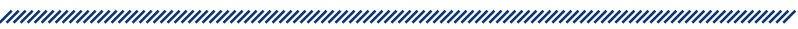

U ovom nas je istraživanju zanimalo utječe li psihička bolest na stilove sučeljavanja sa stresom i na koji način. Stoga smo istraživali postoji li razlika u sučeljavanju oboljelih od depresije, psihotičnih poremećaja i anksioznih poremećaja u odnosu na zdravu populaciju. Rezultati istraživanja govore u prilog postojanja razlike u izboru stilova sučeljavanja kod oboljelih od psihičkih bolesti u odnosu na zdravu populaciju. $U$ našem su se istraživanju oboljeli od psihičkih poremećaja češće koristili slabije adaptiranim stilovima sučeljavanja povezanima s izbjegavanjem, što je u skladu s istraživanjima povezanosti slabije prilagođenih stilova sučeljavanja s psihičkom bolešću. U uzorku zdrave populacije pronađena je statistički značajna razlika u korištenju pozitivnom interpretacijom, koja pripada prilagođenijim stilovima sučeljavanja, što je u skladu s istraživanjima koja govore u prilog povezanosti funkcionalnijih stilova sučeljavanja sa stresom s mentalnim zdravljem. Rezultat da se oboljeli od psihoze također koriste pozitivnom interpretacijom na prvi pogled predstavlja kontradiktoran podatak s obzirom na to da očekujemo korištenje manje adaptabilnim sučeljavanjem, čemu govori u prilog da su stilovi sučeljavanja više povezani s ličnošću nego s bolešću. Korištenje ovim stilom u našem uzorku kod oboljelih od psihoze možemo pripisati i mogućnosti utjecaja psihosocijalnih programa i psihoterapije u kojima su sudjelovali tijekom liječenja, njihovim karakteristikama ličnosti, premorbidno boljem socijalnom funkcioniranju i nekim drugim faktorima. Istraživanje rađeno na kliničkom uzorku pacijenata u Dnevnoj bolnici i u Odjelu za rehabilitaciju pokazuje vi-

\begin{tabular}{|c|c|c|c|c|}
$\begin{array}{c}\text { Tablica 7. Prosječne vrijednosti, raspon i raspršenja rezultata na skalama suočavanja } \\
\text { za skupinu zdrave populacije }\end{array}$ \\
\hline Pozitivna interpretacija & M & SD & Min. & Maks. \\
\hline Aktivno suočavanje & 9,13 & 2,933 & 4 & 15 \\
\hline Planiranje & 8,70 & 2,938 & 1 & 14 \\
\hline Prihvaćanje & 12,37 & 4,311 & 1 & 20 \\
\hline Obuzdavanje suočavanja & 7,57 & 2,459 & 2 & 12 \\
\hline Potiskivanje kompeticijskih aktivnosti & 6,87 & 2,726 & 0 & 13 \\
\hline Negiranje & 5,10 & 2,310 & 0 & 9 \\
\hline Ponašajni dezangažman & 2,07 & 2,067 & 0 & 8 \\
\hline Mentalni dezangažman & 4,00 & 2,197 & 0 & 8 \\
\hline Socijalna podrška emocije & 9,53 & 4,377 & 3 & 22 \\
\hline Socijalna podrška instrumentalno & 8,67 & 4,245 & 1 & 16 \\
\hline Ventiliranje emocija & 8,50 & 3,963 & 1 & 16 \\
\hline Humor & 5,93 & 2,753 & 1 & 11 \\
\hline Alkohol & 4,60 & 2,444 & 1 & 11 \\
\hline Religija & 0,67 & 1,709 & 0 & 7 \\
\hline Fizička izolacija & 4,73 & 4,008 & 0 & 16 \\
\hline Potiskivanje emocija & 3,20 & 2,696 & 0 & 11 \\
\hline Suočavanja usmjerena na problem & 4,37 & 2,930 & 0 & 10 \\
\hline Suočavanje usmjereno na emocije & 10,57 & 3,549 & 4 & 20 \\
\hline Strategije izbjegavanja & 4,57 & 1,736 & 1 & 8 \\
\hline
\end{tabular}




\section{Tablica 8. Prikaz rezultata analize varijance}

\begin{tabular}{|c|c|c|c|c|c|c|}
\hline & & $\begin{array}{c}\text { Suma } \\
\text { kvadrata }\end{array}$ & df & $\begin{array}{l}\text { Sredina } \\
\text { kvadrata }\end{array}$ & $\mathrm{F}$ & Sig. \\
\hline \multirow{3}{*}{ Pozitivna interpretacija } & Među grupama & 156,333 & 3 & 52,111 & 4,861 & 0,003 \\
\hline & Unutar grupe & 1243,667 & 116 & 10,721 & & \\
\hline & Ukupno & 1400,000 & 119 & & & \\
\hline \multirow{3}{*}{ Aktivno suočavanje } & Među grupama & 50,292 & 3 & 16,764 & 1,370 & 0,256 \\
\hline & Unutar grupe & 1419,833 & 116 & 12,240 & & \\
\hline & Ukupno & 1470,125 & 119 & & & \\
\hline \multirow{3}{*}{ Planiranje } & Među grupama & 95,367 & 3 & 31,789 & 1,610 & 0,191 \\
\hline & Unutar grupe & 2290,600 & 116 & 19,747 & & \\
\hline & Ukupno & 2385,967 & 119 & & & \\
\hline \multirow{3}{*}{ Prihvaćanje } & Među grupama & 58,121 & 3 & 19,374 & 2,085 & 0,106 \\
\hline & Unutar grupe & 1068,585 & 115 & 9,292 & & \\
\hline & Ukupno & 1126,706 & 118 & & & \\
\hline \multirow{3}{*}{ Obuzdavanje suočavanja } & Među grupama & 10,892 & 3 & 3,631 & 0,371 & 0,774 \\
\hline & Unutar grupe & 1134,100 & 116 & 9,777 & & \\
\hline & Ukupno & 1144,992 & 119 & & & \\
\hline \multirow{3}{*}{ Potiskivanje kompeticijskih aktivnosti } & Među grupama & 20,625 & 3 & 6,875 & 1,097 & 0,354 \\
\hline & Unutar grupe & 727,300 & 116 & 6,270 & & \\
\hline & Ukupno & 747,925 & 119 & & & \\
\hline \multirow{3}{*}{ Negiranje } & Među grupama & 114,833 & 3 & 38,278 & 4,097 & 0,008 \\
\hline & Unutar grupe & 1083,667 & 116 & 9,342 & & \\
\hline & Ukupno & 1198,500 & 119 & & & \\
\hline \multirow{3}{*}{ Ponašajni dezangažman } & Među grupama & 326,225 & 3 & 108,742 & 11,391 & 0,000 \\
\hline & Unutar grupe & 1107,367 & 116 & 9,546 & & \\
\hline & Ukupno & 1433,592 & 119 & & & \\
\hline \multirow{3}{*}{ Mentalni dezangažman } & Među grupama & 156,033 & 3 & 52,011 & 2,000 & 0,118 \\
\hline & Unutar grupe & 3017,267 & 116 & 26,011 & & \\
\hline & Ukupno & 3173,300 & 119 & & & \\
\hline \multirow{3}{*}{ Socijalna podrška emocije } & Među grupama & 167,025 & 3 & 55,675 & 2,924 & 0,037 \\
\hline & Unutar grupe & 2208,967 & 116 & 19,043 & & \\
\hline & Ukupno & 2375,992 & 119 & & & \\
\hline \multirow{3}{*}{ Socijalna podrška instrumentalno } & Među grupama & 38,000 & 3 & 12,667 & 0,627 & 0,599 \\
\hline & Unutar grupe & 2343,200 & 116 & 20,200 & & \\
\hline & Ukupno & 2381,200 & 119 & & & \\
\hline \multirow{3}{*}{ Ventiliranje emocija } & Među grupama & 25,100 & 3 & 8,367 & 0,891 & 0,448 \\
\hline & Unutar grupe & 1089,267 & 116 & 9,390 & & \\
\hline & Ukupno & 1114,367 & 119 & & & \\
\hline \multirow{3}{*}{ Humor } & Među grupama & 55,200 & 3 & 18,400 & 2,206 & 0,091 \\
\hline & Unutar grupe & 967,600 & 116 & 8,341 & & \\
\hline & Ukupno & 1022,800 & 119 & & & \\
\hline \multirow{3}{*}{ Alkohol } & Među grupama & 422,833 & 3 & 140,944 & 8,567 & 0,000 \\
\hline & Unutar grupe & 1908,467 & 116 & 16,452 & & \\
\hline & Ukupno & 2331,300 & 119 & & & \\
\hline
\end{tabular}




\begin{tabular}{|c|c|c|c|c|c|c|}
\hline & & $\begin{array}{c}\text { Suma } \\
\text { kvadrata }\end{array}$ & df & $\begin{array}{c}\text { Sredina } \\
\text { kvadrata }\end{array}$ & $\mathrm{F}$ & Sig. \\
\hline \multirow{3}{*}{ Religija } & Među grupama & 226,567 & 3 & 75,522 & 2,810 & 0,043 \\
\hline & Unutar grupe & 3117,800 & 116 & 26,878 & & \\
\hline & Ukupno & 3344,367 & 119 & & & \\
\hline \multirow{3}{*}{ Fizička izolacija } & Među grupama & 726,233 & 3 & 242,078 & 15,903 & 0,000 \\
\hline & Unutar grupe & 1765,733 & 116 & 15,222 & & \\
\hline & Ukupno & 2491,967 & 119 & & & \\
\hline \multirow{3}{*}{ Potiskivanje emocija } & Među grupama & 180,400 & 3 & 60,133 & 5,278 & 0,002 \\
\hline & Unutar grupe & 1321,600 & 116 & 11,393 & & \\
\hline & Ukupno & 1502,000 & 119 & & & \\
\hline \multirow{3}{*}{ Suočavanja usmjerena na problem } & Među grupama & 71,400 & 3 & 23,800 & 1,397 & 0,247 \\
\hline & Unutar grupe & 1976,067 & 116 & 17,035 & & \\
\hline & Ukupno & 2047,467 & 119 & & & \\
\hline \multirow{3}{*}{ Suočavanje usmjereno na emocije } & Među grupama & 6,867 & 3 & 2,289 & 0,530 & 0,663 \\
\hline & Unutar grupe & 501,000 & 116 & 4,319 & & \\
\hline & Ukupno & 507,867 & 119 & & & \\
\hline \multirow{3}{*}{ Strategije izbjegavanja } & Među grupama & 52,025 & 3 & 17,342 & 0,701 & 0,553 \\
\hline & Unutar grupe & 2869,900 & 116 & 24,741 & & \\
\hline & Ukupno & 2921,925 & 119 & & & \\
\hline
\end{tabular}

šu razinu funkcioniranja. Stoga su naši rezultati u skladu s istraživanjem Vrdoljaka o socijalnom funkcioniranju osoba s dijagnozom shizofrenije u odnosu na načine sučeljavanja sa stresom ${ }^{18}$. Njegovi rezultati pokazuju da se osobe koje imaju manja oštećenja socijalnog funkcioniranja koriste povoljnijim načinima sučeljavanja u stresnoj situaciji.

Statistički značajno korištenje negiranjem kao stilom sučeljavanja kod anksioznih i oboljelih od psihoze očekivani je rezultat, jer se negiranje ubraja u slabije prilagođene stilove sučeljavanja, čiju povećanu učestalost očekujemo kod oboljelih od psihičkih poremećaja. Također je očekivani rezultat da će se oboljeli od psihičkih poremećaja češće koristiti ponašajnim dezangažmanom u odnosu na zdravu populaciju s obzirom na to da je korištenje izbjegavajućim ponašanjem kao stilom nošenja sa stresom češće kod oboljelih od psihičkih poremećaja, što je u skladu s istraživanjima drugih stručnjaka²5, 23, 12. Međutim, kada se analiziraju stilovi sučeljavanja koji uključuju više stilova svrstanih u stilove sučeljavanja povezane s problemom, povezane s emocijama i izbjegavanjem, nema statistički značajne razlike u odnosu na zdravu populaciju i oboljele od psihičkih poremećaja. Ovaj podatak iznenađuje, s obzirom na to da smo očekivali da će u skladu s drugim istraživanjima biti razlike $u$ odnosu na emocionalni stil sučeljavanja koji smo očekivali naći kod oboljelih od depresije $^{6,7,8}$. Također smo očekivali češće korištenje stilovima izbjegavanja i manje korištenje sučeljavanjem okrenutim prema rješavanju problema ${ }^{12,13}$. Neusklađenost naših rezultata $s$ drugim istraživanjima možemo objasniti malim uzorkom, utjecajem psihoterapijskog procesa kojem su bili izloženi, osobnim karakteristikama ličnosti i mogućnošću utjecaja nekih drugih faktora koji mogu djelovati na sučeljavanje. Ponovno napominjemo da su u istraživanju sudjelovali pacijenti koji su prošli liječenje u Dnevnoj bolnici u kojoj se primjenjuju psihosocijalne metode liječenja ili je njihovo liječenje bilo u tijeku. Istraživanje je potvrdilo značaj različitih faktora na stilove sučeljavanja, kao što su bračni status, zaposlenost i spol.

U skupini osoba s psihozama pokazalo se da su se oženjeni češće koristili alkoholom kao stilom sučeljavanja (što pripada stilu izbjegavanja) od neoženjenih i razvedenih koji se više koriste religijom. U skupni oboljelih od anksioznih poremećaja pokazala se statistički značajna razlika između zaposlenih i nezaposlenih u korištenju religijom kao stilom sučeljavanja, pri čemu su zaposleni 
skloniji religiji u odnosu na nezaposlene. Razlika u sučeljavanju u odnosu na spol pronađena je jedino u uzorku oboljelih od depresije. U skupini oboljelih od depresije uočila se statistički značajna razlika između muškaraca i žena kada govorimo o potiskivanju kao stilu sučeljavanja. Žene u ovoj skupini statistički su se značajno češće koristile potiskivanjem emocija kao stilom sučeljavanja u odnosu na muškarce. Ovi su podatci u skladu s podatcima iz literature, međutim različiti su od podataka iz literature gdje se žene više koriste emocionalno fokusiranim sučeljavanjem ${ }^{8}$. U ovom su se uzorku žene koristile emocionalnim potiskivanjem, što ponovno govori u prilog složenosti i multidimenzionalnosti stila sučeljavanja na koji djeluju brojni faktori.

Potrebno je naglasiti da su sve ranije navedene razlike, kao i ova, vjerojatno jednim dijelom i odraz neravnomjernog omjera u kojem je unutar svake kategorije zastupljen spol, zaposlenost, obrazovni status itd. Očekivali smo da će se oboljeli koji su bili češće hospitalizirani koristiti slabije prilagođenim načinima sučeljavanja. Istraživanje nije potvrdilo utjecaj broja hospitalizacija i dužine liječenja na stilove sučeljavanja. U ovom su uzorku najveći broj hospitalizacija imali oboljeli od psihotičnih poremećaja, ali to nije utjecalo na specifičnosti sučeljavanja. Ovaj rezultat govori u prilog tome da su stilovi sučeljavanja više povezani s ličnošću nego $\mathrm{s}$ bolešću.

Rezultati istraživanja o stilovima sučeljavanja između oboljelih od psihičkih poremećaja i zdrave populacije potvrđuju da postoji razlika u sučeljavanju u smislu češćeg korištenja funkcionalnijim mehanizmima sučeljavanja u odnosu na oboljele od psihičkih poremećaja. $S$ druge strane, nismo pronašli specifične načine sučeljavanja u odnosu na pojedine dijagnostičke skupine, što govori u prilog podatcima iz literature da sučeljavanje ovisi o brojnim faktorima, od kojih je dimenzija ličnosti vrlo značajna. Ovo ne umanjuje značaj stilova sučeljavanja u nastanku ishoda mentalnog poremećaja, već upućuje na potrebu individualne procjene utjecaja stresa te prepoznavanje stilova sučeljavanja i rada na korištenju efikasnijim stilovima sučeljavanja, što bi moglo utjecati na povoljniji ishod liječenja i prevenciju ponovnog pogoršanja bolesti. Stoga je potrebno procjenjivati stilove sučeljavanja u svakom pojedinačnom slučaju bez obzira na dijagnozu, kako bi se intervencijom u tom području pomoglo pacijentima da postignu bolje rezultate liječenja. Rezultate ovog istraživanja, naravno, treba uzeti s oprezom zbog malog uzorka i neravnomjernosti uzorka s obzirom na spol, zaposlenje i druge faktore.

\section{Zaključak}

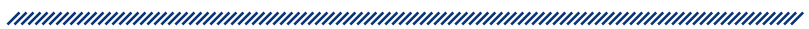

Ovim smo istraživanjem testiranjem značajnosti razlika u stilovima sučeljavanja sa stresom između skupina oboljelih od psihičke bolesti i zdravih pokazali razlike u: pozitivnoj interpretaciji, negiranju, ponašajnom dezangažmanu, alkoholu, fizičkoj izolaciji i potiskivanju emocija. Pozitivnom su se interpretacijom češće koristile zdrava populacija i skupina oboljelih od psihotičnog poremećaja u odnosu na osobe s depresivnim poremećajem, a negiranje je kao strategija sučeljavanja prevladavala kod sudionika iz skupine s anksioznim poremećajem i skupine s psihotičnim poremećajem u odnosu na zdravu populaciju. Ponašajni dezangažman pokazao se kao strategija sučeljavanja u sve tri skupine oboljelih od psihičkih poremećaja, ali između pojedinih skupina nije bilo razlike između stilova sučeljavanja povezanih s problemom, stilova sučeljavanja povezanih s emocijama te stilova izbjegavanja. U skupini oboljelih od psihotičnog poremećaja pokazalo se da postoji statistički značajna razlika između oženjenih i grupe neoženjenih i samaca u korištenju alkoholom kao stilom sučeljavanja. Oženjeni su se pokazali skloniji alkoholu u odnosu na neoženjene i razvedene. $U$ istoj se skupini pokazala razlika i u religioznosti. Neoženjeni i razvedeni bili su skloniji religiji, dok je u skupni oboljelih od anksioznih poremećaja bilo razlike između zaposlenih i nezaposlenih u korištenju religijom kao stilom sučeljavanja. Zaposleni su bili skloniji religiji kao stilu sučeljavanja u odnosu na nezaposlene. Postoji statistički značajna razlika između muškaraca i žena u grupi sudionika s depresivnim poremećajem kada govorimo o potiskivanju kao stilu sučeljavanja. Žene u ovoj skupini češće se koriste potiskivanjem emocija kao stilom sučeljavanja u odnosu na muškarce. Pokazala se razlika u stupnju obrazovanja i korištenja mentalnim dezangažmanom, kojim su se češće koristili sudionici sa završenom srednjom školom. 


\section{Literatura}

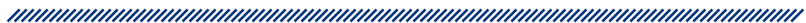

1. Havelka M. Zdravstvena psihologija. Jastrebarsko: Naklada Slap, 1998.

2. Lazarus RS, Folkman S. Stress, appraisal, and coping. New York: Springer, 1984.

3. Endler NS, Parker JDA. Multdimensional assessment of coping: A critical evaluation. Journal of Personality and Social Psychology. 1990;58:844-854.

4. Carver CS, Scheier MF, Weintraub JK. Assessing coping strategies: a theoretically based approach. Journal of Personality and Social Psychology. 1989;59:73-81.

5. Alloy LB, Clements CM. Illusion of control: inbulnerability to negative affect and depressive symptoms after laboratory amd natural stressors. Journal of Abnormal Psychology. 1992;101:234-245.

6. Ravindran AV, Anisman H, Merali Z, Charbonneau Y, Teiner J, Bialik RJ, Weins A, Ellis J, Griffiths J. Treatment of primary dysthymia with cognitive therapy and pharmacotherapy: clinical symptoms and functional impairments. American Journal of Psychiatry. 1999;156:1608-1617.

7. Ravindran AV, Matheson K, Griffiths J, Merali Z, Anisman $H$. Stress, coping, uplifts, and quality of life in subtypes of depression: a conceptual model and emerging data. Journal of Affective Disorders. 2002;71:121-130.

8. Leandro PG, Castillo D. Coping with stress and its relationship with personality dimensiones anxiety, and depression. Procedia - Social and Behavioral Sciences. 2010;5:1562-1573.

9. Nolen-Hoekaema S. Ruminative coping with depression. In: Heckhaisen J, Dweck CS. Motivation and Self Regulation Across the Life Span. Cambridge: Cambridge university press 1998; 237-256.

10. Endler NS, Parker JDA. Assessment of multidimensional coping: task, emotion and avoidance strategies. Psychological Assessment. 1994;6:50-60.

11. Holohan CJ, Moos RH, Holohan CK, Cronkite RC. Resource loss, resource gain and depressive symptoms: a 10 year model. Journal of Personality and Social Psychology. 1999; 77:620-629.

12. Billings AG, Cronkite RC, Moos RH. Social-environmental factors in unipolar depression: Comparisons of depressed patiens and nondepressed controls. Journal of Abnormal Psychology. 1983;92:119-133.

13. Coyne JC, Aldwin C, Lazarus RS. Depression and coping in stressful episodes. Journal of Abnormal Psychology. 1981;90:439-447.

14. Rios Martinez BP, Chavez Leon E, Rangel Rodrigez GA, Pedraza Moctezuma LG. Defense mechanisms in cardiovascular disease patients. Salud Mental. 2010;33:219-227.

15. Gispen-de Wied CC. Stress in shizophrenia: an integrative view. European Journal of Pharmacology. 2000;405(13):375-84.
16. Van den Bosch RJ, Rombouts RP. Coping and cognition in Schizophrenia and Depression. Comprenhensive Psychiatry. 1993;34(2):130-136.

17. Ritsner M, Kurs R, Gibel A, Hirschmann S, Shinkarenko E, Ratner Y. Predictors of quality of life in major paychoses: a naturalistic follow-up study. Journal of Clinical Psychiatry. 2003;64(3):308-15.

18. Vrdoljak M. Socijalno funkcioniranje osoba s dijagnozom shizofrenija u odnosu na načine sučeljavanja sa stresom. Magistarski rad. Zagreb: Medicinski fakultet Sveučilišta u Zagrebu; 2005.

19. Zubin J, Spring B. Vulnerability - a new view of shizophrenia. Journal of Abnormal Psychology. 1977;86(2):103-126.

20. Zubin J, Steinhauer SR, Condray R. Vulnerability to relapse in schizophrenia. The British Journal of Psychiatry Supplement. 1992; (18):13-8.

21. Nuechterlein KH, Dawson ME. A heuristic vulnerability/ stress model of schizophrenic episodes. Schizophrenia Bulletin. 1984;10:300-312.

22. Ivezić S. Rehabilitacija u psihijatriji: psihobiosocijalni pristup. Zagreb: Hrvatski liječnički zbor; 2010.

23. Carver CS, Scheier MF, Weintraub JK. Assessing coping strategies: a theoretically based approach. Journal of Personality and Social Psychology. 1989;59:73-81.

24. Hudek-Knežević J, Kardum I. Upitnik dispozicijskog i situacijskog sučeljavanja sa stresom i njihove psihometrijske značajke. Godišnjak Zavoda za psihologiju. 1993;43-60.

25. Van den Bosch RJ, Rombouts RP. Coping and cognition in schizophrenia and depression. Comprehensive Psychiatry. 1997;38(6):341-4. 


\section{STRESS COPING STYLES IN RELATION TO VARIOUS PSYCHIATRIC DISORDERS}

1 Zlata Pjević

1 Slađana Štrkalj Ivezić

2 Anja Melada

1 University Psychiatric Hospital Vrapče, Zagreb, Croatia

2 Department of Psychiatry, University Hospital Dubrava, Zagreb, Croatia

\section{Abstract}

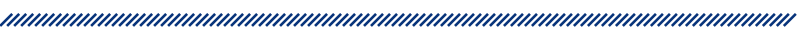

Introduction: Stress is one of the most common triggers of processes that lead to psychiatric disorders. Our objective was to determine whether there are differences in coping styles among participants with psychiatric disorders compared to a healthy population and differences in coping styles between the participants with psychiatric disorders due to demographic characteristics. Methods: Participants: The study included 120 participants divided into 4 groups of 30 participants. The participants diagnosed with a psychiatric disorder were divided into three groups: participants with a depressive disorder, anxiety disorders and psychotic disorders, and by gender, level of education, age, employment, marital status, length of treatment and number of hospitalizations. The fourth group consisted of healthy participants. Instruments: The adapted version of the dispositional form of the COPE questionnaire (Coping Orientation to Problems Experienced) was used. Results: Between the groups of participants with mental disorders and the healthy participants, coping styles showed statistically significant differences in positive interpretation, denial, behavioral disengagement, alcohol use, physical isolation and the suppression of emotions as well differences in terms of gender, age, marital status, occupation and employment. Discussion: Differences in coping styles in patients with psychiatric disorders are not specific to their psychopathology which is consistent with studies of other researchers. Participants in our study had finished or were in treatment as outpatients where psychosocial treatments are used, which could have affected their coping styles. Conclusion: The results of the study confirm that healthy people compared to people with psychiatric disorders use functional coping styles. We did not find specific coping styles in relation to a particular diagnostic group, which supports the data that coping depends on a number of factors.

Keywords : stress, coping with stress, coping styles, psychobiosocial model, psychosocial interventions 